${ }^{\circledR}$ Entomologica Fennica. 12 December 1994

\title{
Wing variation of Maculinea arion (Linnaeus) in Finland (Lepidoptera, Lycaenidae)
}

\author{
Rauno Väisänen, Kari Heliövaara \& Päivö Somerma
}

\begin{abstract}
Väisänen, R., Heliövaara, K. \& Somerma, P. 1994: Wing variation of Maculinea arion (Linnaeus) in Finland (Lepidoptera, Lycaenidae). — Entomol. Fennica 5:139-146.
\end{abstract}

Wing variation in the large blue butterfly, Maculinea arion (Linnaeus, 1758), was studied using 22 measurements of the wing shape, venation and coloration in males and females of Finnish and Karelian populations. The results showed that the spots were fewer and smaller in the western populations than in the eastern ones, whereas the black marginal stripe was wider in the west. The samples from the western populations (Lohja, Kangasala, Hattula, Asikkala, etc.) formed a distinctive group differing from the eastern populations (Taipalsaari, Liperi, Isthmus of Karelia). The temporal within-population variation in Asikkala was relatively high compared to the between-population variation within both the western and eastern population groups.

Rauno Väisänen, Nature Conservation Research Unit, National Board of Waters and the Environment, P.O. Box 250, FIN-00101 Helsinki, Finland Kari Heliövaara, Department of Applied Zoology, P.O. Box 27, FIN-00014 University of Helsinki

Päivö Somerma, Department of Zoology, P.O. Box 17 (P. Rautatiek. 13), FIN-00014 University of Helsinki, Finland

Received 15 May 1993, accepted 21 February 1994

\section{Introduction}

Intraspecific variation is an important component of biodiversity. Since there are few if any truly endemic species in Finland, conservation efforts should be focused also on subspecies and intrasubspecifically differentiated populations. The conservation value of marginal populations varies depending on the degree of isolation and associated differentiation. So far most attention has been paid to vascular plants, birds and mammals, while intraspecific variation in invertebrates has remained virtually unknown.

The large blue butterfly, Maculinea arion (Linnaeus), is an endangered species in Finland
(Rassi et al. 1986, 1992) and in all of Europe (Heath 1981, Thomas 1983, 1984). Small larvae of $M$. arion live on Thymus spp., but later the species is dependent on the presence of ants (Myrmica sabuleti Meinert) (Thomas 1984, Elmes \& Thomas 1992, Thomas \& Wardlaw 1992). The larvae are carried into ant nests where they feed on small ant larvae. Secretion produced by the butterfly larva is, in turn, utilized by the ants.

Several local populations of $M$. arion have been lost in Finland (e.g. Järventausta et al. 1988), apparently owing to changes in land use and cessation of forest fires, resulting in a highly disjunct distribution (see also Muggleton \& Benham 1975). Low undergrowth has been replaced by slightly 


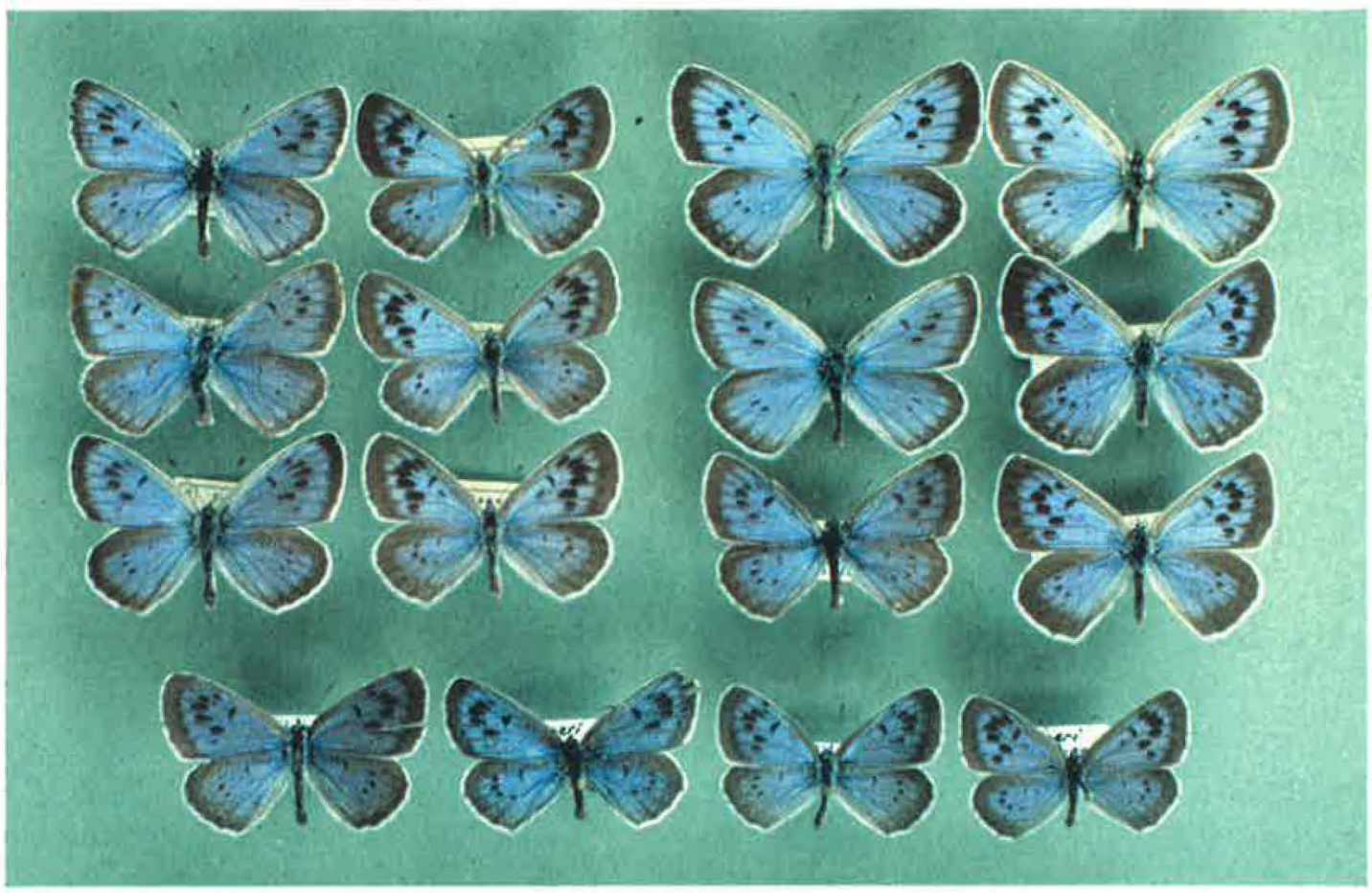

Fig. 1. Phenotypic variation of Maculinea arion from Finland. Males on the left, females on the right. The localities are Liperi (four old specimens, collected prior to 1961, the bottom row), Lohja (six old specimens on the upper right) and Asikkala (six more recently collected specimens on the upper left).

higher plants, which has favoured non-host ant species (e.g. Elmes \& Thomas 1992). Afforestation and gravel pits have destroyed some habitats. The Finnish distribution of $M$. arion follows eskers and sandy Salpausselkä ridges. M. arion occurs also in Denmark, Sweden and Estonia (Nordström et al. 1955, Thomson 1967, Henriksen \& Kreutzer 1982, Kesküla 1992). Its range extends from southern Europe to Siberia and China in the east.

Morphological differences in allopatric butterfly populations can be conspicuous (e.g. Brakefield \& Shreeve 1992). If the differences are small, quantitative morphometric methods can be used in the comparison of populations. $M$. arion often has isolated populations which tend to differ in their wing pattern (Fig. 1). Consequently, several forms and subspecies have been described (e.g. Higgins \& Riley 1970, Henriksen \& Kreutzer 1982). Dempster (1991) published a study on changes in the ratio of thoracic width to thoracic length in $M$. arion in Britain. No systematic studies have been carried out on the morphometric variation of $M$. arion in Finland. The aim of the present study is to analyse the wing variation of the species and to investigate the degree of difference between local populations in Finland and on the Isthmus of Karelia. The difference of old and new samples from Asikkala are also compared to each other to obtain a picture on the magnitude of temporal variation.

\section{Material and methods}

\subsection{Material}

The study area was restricted to eastern Fennoscandia and material from southern and eastern Finland and the Isthmus of Karelia were used in the analysis. The material consisted of 229 specimens (166 males and 63 females) in the col- 


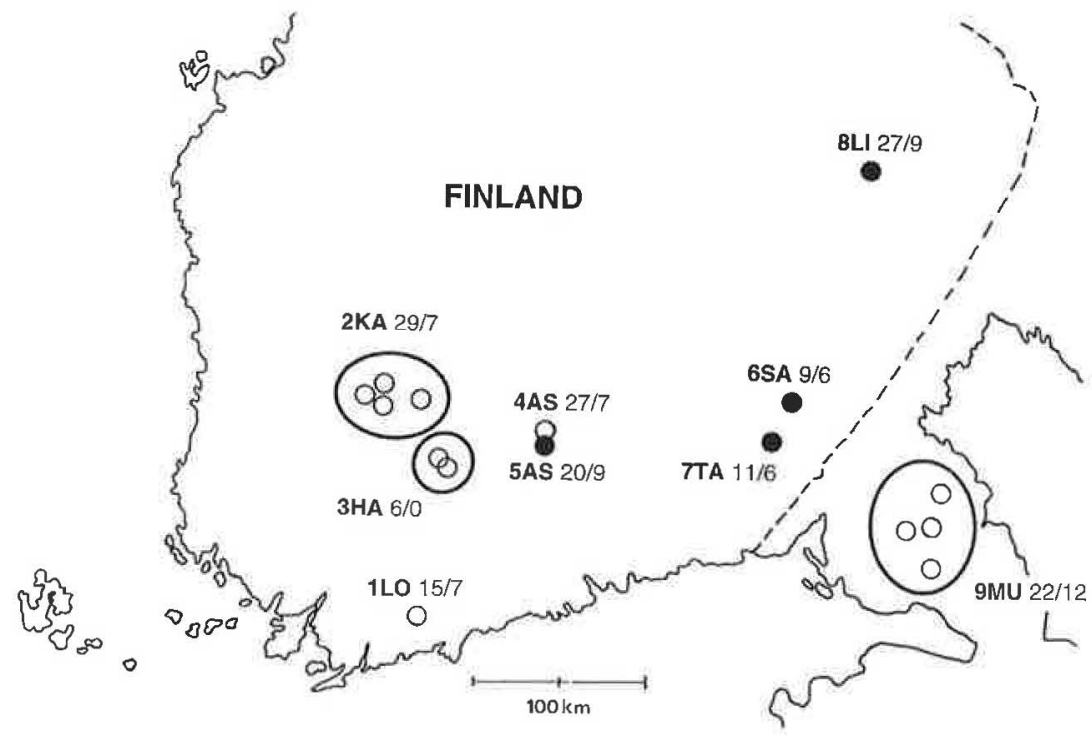

Fig. 2. The distribution of Maculinea arion in eastern Fennoscandia. The numbers refer to the populations (or population groups) used in the statistical analysis (Table 1). Open circles = "old" material collected prior to 1961, mostly 1914-1940; black dots = samples taken 1960 onwards. Sample codes: 1LO = N: Lohja; 2KA = Ta: Kangasala, Pirkkala, Ylöjärvi, Nokia; 3HA = Ta: Hattula, Parola; 4AS and 5AS = Ta: Asikkala, Vääksy; 6SA = "Saimaa"; 7TA = Ka: Taipalsaari; 8LI = Kb: Liperi; 9MU = Ik (Russia): Muolaa, Valkjärvi, Kivennapa, Metsäpirtti.

lections of the Zoological Museum, University of Helsinki, and in private collections (coll. H. Holmberg, P. Koskinen, G. Nordenswan, P. Somerma). The specimens were grouped into 9 samples belonging to 8 populations or geographically limited groups of populations (Fig. 2). In addition to these populations, only scattered specimens are available.

\subsection{Measurements}

The variables measured were either shape variables (the shape of the wing and the pattern of veins) or colour variables (the spot or colour pattern of the wing). Nomenclature of wing veins follows Higgins (1975). Altogether 19 metric variables were measured on each individual to the nearest $0.25 \mathrm{~mm}$. In addition, 3 numeric variables (V6, V21, V22) refer to the number of certain spots (Fig. 3). All measurements were made by one person (Pirjo Leppänen) using a binocular microscope.

\subsection{Statistical analysis}

Canonical discriminant analysis (CANDISC, SAS multivariate procedures, Cary, N. C.) was the main statistical method used. In this method, canonical analysis is carried out to find linear combinations of the variables that best depict the differences among the populations. Given two or more groups of observations with measurements on several quantitative variables, canonical discriminant analysis derives a linear combination of variables that has the highest possible multiple correlation with the groups. The second canonical correlation is obtained by finding the linear combination, uncorrelated with the first canonical variable, that has the highest possible multiple correlation with the groups. The numbered "populations" (i.e. populations or population groups) given in Fig. 2 were used in the analysis. The analysis was carried out separately for males and females using all metric variables. Mahalanobis distances $D^{2}$ computed through the $F$-statistics matrix permits assessment of the 


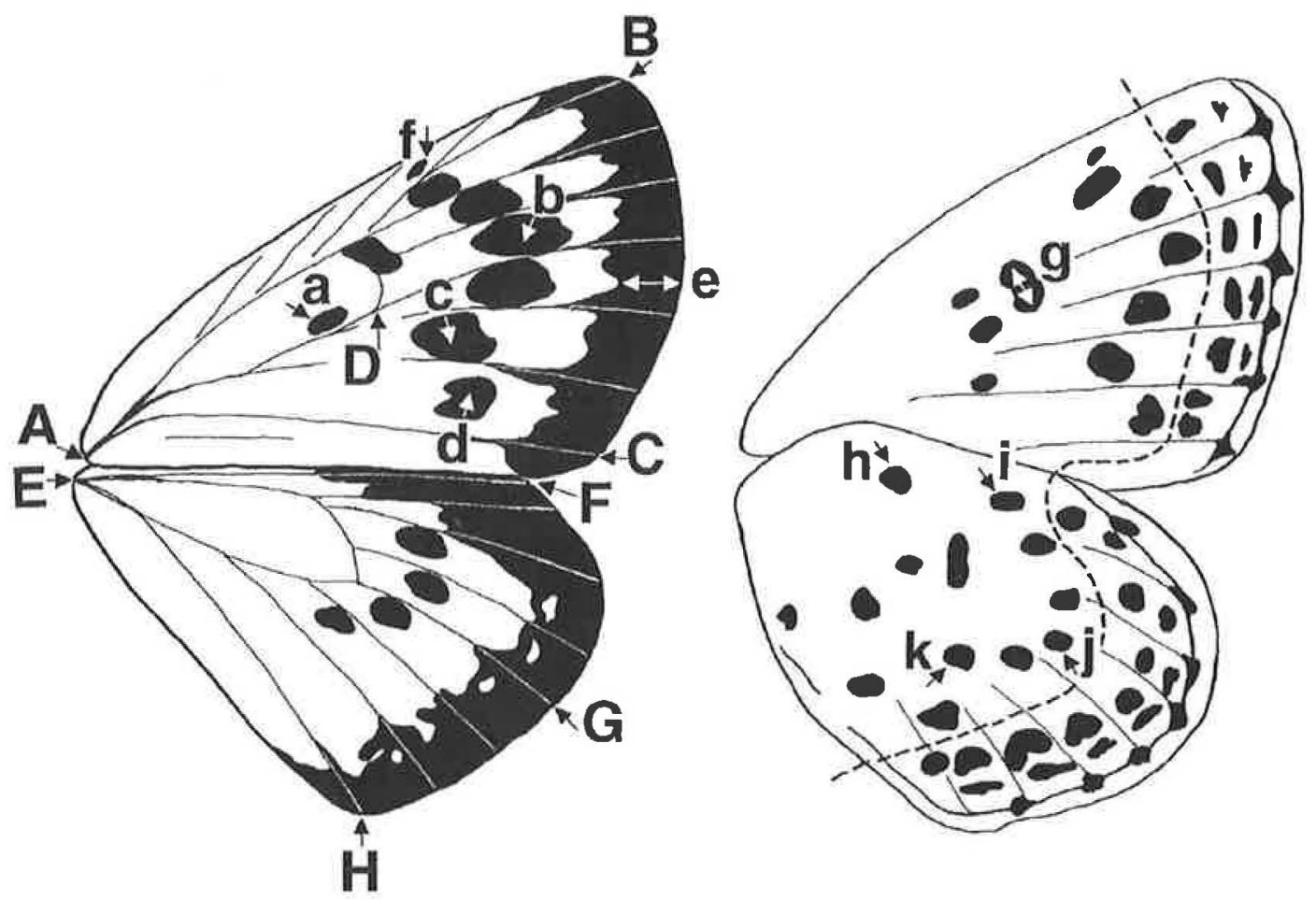

Fig. 3. The 20 morphometric measurements made on Maculinea arion. Spots and fixed points for measurements on wing upper and under side indicated by letters. Variable measured on wing upper side: $V 1-4=$ maximum diameters of spots $\mathrm{a}-\mathrm{d}$, respectively; $\mathrm{V} 5=$ minimum width of black margin between veins 3 and 4 (e); $\mathrm{V} 6=$ presence or absence of 'subcostal' spot f; V7 = distance A-B; V8 = B-D; V9 = C-D; V10 = B-C; V11 = E-G; V12 $=F-G ; V 13=F-H$. Wing under side: $V 14-15=$ maximal diameters of spots $g$ and $; ; \mathrm{V} 16-20=$ distances between spots $\mathrm{h}-\mathrm{j}, \mathrm{h}-\mathrm{k}, \mathrm{h}-\mathrm{i}, \mathrm{i}-\mathrm{j}, \mathrm{j}-\mathrm{k}$, respectively; $\mathrm{V} 21-22$ = number of underside 'discal' spots (proximal to broken line, $>0.5 \mathrm{~mm}$ ) on front wing and on hind wing.

relative similarity of group centroids of different populations. Populations sharing small $D^{2}$ values can be considered more alike than those with higher values. In order to interpret the matrix of $D^{2}$ values, a cluster analysis (Program NCLAS, SYN-TAX IV; Podani 1990) was constructed by average linkage (UPGMA). Similar clustering has been used e.g. by Battin (1992) for the Aegean damselflies.

\section{Results}

The means of numerical variables indicated that the western populations, especially males, had fewer spots than eastern populations on both wings (Table 1). The mean number of discal spots (including 'basal' spots) on male fore wing underside (V21) varied from 7.0 to 7.5 among the western populations from Lohja to Asikkala (1LO, 2KA, 3HA, 4AS, 5AS), and between 7.7 and 8.5 among the eastern populations (6SA, 7TA, 8LI, 9MU). In the females, the means were $7.1-8.1$ and 7.7-9.0, respectively. Similarly, the mean number and discal spots on the male hind wing underside (V22) varied between 8.8 and 9.7 among the western populations, and between 10.4 and 11.6 among the eastern ones. For the females the respective values were 9.4-10.9 and 11.2-12.3. The subcostal spot (V6) was missing in all western females and in almost all western males, but it was commonly present in eastern individuals (with the exception of 6SA). The largest males (measured as the value of V7) were found from Taipalsaari (7TA: mean $18.46 \mathrm{~mm}$ ) and the smallest from Hattula (HA3: $17.55 \mathrm{~mm}$ ). Respectively, the largest females originated from Lohja (1LO: mean $19.62 \mathrm{~mm}$ ) and, in contrast to 
the males, the smallest from Taipalsaari (7TA: $17.97 \mathrm{~mm}$ ). However, the size variables differed less between populations than the variables associated with spot pattern, and most differences were statistically non-significant.
The main results from the canonical discriminant analysis of the metric variables are given separately for $M$. arion males and females in Table 2. The eigenvalues can be interpreted as the ratio between the between-population varia-

Table 1. Mean values of Maculinea arion variables with statistically significant between-population differences in univariate analyses ( $F$ statistics for V $1-5$ and V7-20; chi-square statistics for V6; and Kruskall-Wallis $H$-statistics for V21-22). For comparison, V22 is also given for females. ${ }^{\star * *}=P<0.001,{ }^{\star \star}=P<0.01,{ }^{\star}=P<0.05, N S=P>0.05$.

\begin{tabular}{|c|c|c|c|c|c|c|c|c|c|c|}
\hline \multirow[t]{2}{*}{ Variable } & \multicolumn{2}{|c|}{ Population } & \multirow[b]{2}{*}{$3 \mathrm{HA}$} & \multirow[b]{2}{*}{$4 A S$} & \multirow[b]{2}{*}{$5 A S$} & \multirow[b]{2}{*}{$6 \mathrm{SA}$} & \multirow[b]{2}{*}{ 7TA } & \multirow[b]{2}{*}{ 8LI } & \multirow[b]{2}{*}{$9 \mathrm{MU}$} & \multirow{2}{*}{$\begin{array}{l}\text { Statistic } \\
\text { value }\end{array}$} \\
\hline & $1 \mathrm{LO}$ & $2 \mathrm{KA}$ & & & & & & & & \\
\hline \multicolumn{11}{|l|}{ Males } \\
\hline V1 & 0.09 & 0.14 & 0.18 & 0.22 & 0.08 & 0.35 & 0.57 & 0.41 & 0.55 & $2.35^{\star}$ \\
\hline V2 & 2.37 & 2.35 & 2.60 & 2.60 & 1.97 & 3.09 & 3.26 & 2.99 & 2.85 & $6.74^{\star \star \star}$ \\
\hline V4 & 0.68 & 1.28 & 0.99 & 1.01 & 0.72 & 0.86 & 1.89 & 1.85 & 1.39 & $3.53^{\star \star \star \star}$ \\
\hline V5 & 1.49 & 1.56 & 1.60 & 1.35 & 1.41 & 1.21 & 1.05 & 1.17 & 0.99 & $4.78^{\star \star \star}$ \\
\hline V6 & 0.00 & 0.00 & 0.00 & 0.04 & 0.05 & 0.00 & 0.55 & 0.78 & 0.50 & $82.37^{\star \star \star}$ \\
\hline V12 & 4.31 & 4.88 & 4.67 & 4.61 & 4.66 & 4.80 & 4.93 & 4.69 & 4.88 & $3.87^{\star \star \star}$ \\
\hline V14 & 1.91 & 1.84 & 1.93 & 1.85 & 1.94 & 1.88 & 1.81 & 1.84 & 1.72 & $2.99^{\star \star}$ \\
\hline V15 & 1.19 & 1.08 & 1.05 & 1.09 & 1.17 & 1.36 & 1.35 & 1.29 & 1.15 & $3.53^{* \star \star}$ \\
\hline V18 & 4.69 & 4.30 & 4.38 & 4.63 & 5.02 & 4.61 & 4.79 & 5.12 & 5.00 & $7.57^{\star \star \star}$ \\
\hline V20 & 4.19 & 4.07 & 3.88 & 4.19 & 4.17 & 4.20 & 4.31 & 4.20 & 4.41 & $2.24^{*}$ \\
\hline V21 & 7.47 & 7.00 & 7.00 & 7.52 & 7.10 & 8.22 & 8.45 & 8.50 & 7.68 & $35.21^{\star \star \star}$ \\
\hline V22 & 9.67 & 9.17 & 8.83 & 9.44 & 9.70 & 11.56 & 10.82 & 10.41 & 10.73 & $26.03^{* * *}$ \\
\hline \multicolumn{11}{|l|}{ Females } \\
\hline V1 & 0.50 & 0.53 & & 0.33 & 0.19 & 1.84 & 0.79 & 1.42 & 1.04 & $5.96^{\star \star \star}$ \\
\hline V2 & 2.63 & 2.78 & & 2.65 & 2.06 & 3.33 & 3.03 & 3.66 & 3.31 & $4.16^{\star \star \star}$ \\
\hline V3 & 2.47 & 2.25 & & 2.37 & 2.14 & 2.83 & 2.22 & 3.25 & 3.05 & $2.59^{\star}$ \\
\hline V4 & 2.03 & 1.73 & & 1.30 & 1.42 & 3.30 & 2.45 & 2.76 & 2.41 & $3.28^{\star \star}$ \\
\hline V6 & 0.00 & 0.00 & & 0.00 & 0.00 & 0.17 & 0.83 & 1.00 & 0.50 & $42.00^{\star \star \star}$ \\
\hline V9 & 8.85 & 7.92 & & 8.17 & 8.07 & 7.67 & 7.53 & 8.07 & 8.23 & $2.63^{*}$ \\
\hline V11 & 16.53 & 15.23 & & 15.58 & 15.72 & 15.34 & 14.73 & 15.01 & 15.65 & $2.22^{\star}$ \\
\hline V13 & 12.17 & 11.32 & & 11.28 & 11.41 & 11.11 & 10.33 & 11.16 & 11.67 & $3.17^{\star \star}$ \\
\hline V14 & 2.25 & 1.93 & & 1.87 & 2.08 & 1.98 & 1.78 & 1.91 & 1.81 & $7.23^{\star \star \star}$ \\
\hline V15 & 1.23 & 1.13 & & 0.93 & 1.19 & 1.34 & 1.14 & 1.38 & 1.33 & $4.79^{\star \star \star}$ \\
\hline V18 & 4.90 & 4.48 & & 4.67 & 4.88 & 4.55 & 4.55 & 5.21 & 5.28 & $4.27^{\star \star \star}$ \\
\hline V20 & 4.53 & 4.35 & & 4.18 & 4.38 & 4.26 & 3.94 & 4.41 & 4.62 & $2.63^{\star}$ \\
\hline V21 & 8.14 & 7.29 & & 7.14 & 7.78 & 9.00 & 7.67 & 8.56 & 8.00 & $13.90^{*}$ \\
\hline V22 & 10.86 & 9.43 & & 9.43 & 10.44 & 12.33 & 11.17 & 11.78 & 11.17 & 0.98 NS \\
\hline
\end{tabular}

Table 2. Results from the canonical discriminant analysis carried out on male and female Maculinea arion. The highest correlations are the highest total-sample correlations between the first three canonical variables (CV1, CV2, CV3) and the original variables.

\begin{tabular}{|c|c|c|c|c|c|c|c|c|c|c|c|c|}
\hline & \multicolumn{6}{|c|}{ Males } & \multicolumn{6}{|c|}{ Females } \\
\hline & \multicolumn{2}{|l|}{ CV1 } & \multicolumn{2}{|l|}{ CV2 } & \multicolumn{2}{|l|}{ CV3 } & \multicolumn{2}{|l|}{ CV1 } & \multicolumn{2}{|c|}{$\mathrm{CV} 2$} & \multicolumn{2}{|l|}{ CV3 } \\
\hline Eigenvalue & 1.74 & & 0.65 & & 0.64 & & 4.34 & & 1.83 & & 0.94 & \\
\hline Percent variance explained: & 0.42 & & 0.16 & & 0.15 & & 0.49 & & 0.21 & & 0.11 & \\
\hline $\begin{array}{l}\text { cumulative } \% \\
\text { Highest correlations }\end{array}$ & 0.42 & & 0.58 & & 0.73 & & 0.49 & & 0.70 & & 0.81 & \\
\hline Positive & V2 & 0.49 & V12 & 0.50 & V18 & 0.36 & V14 & 0.63 & V18 & 0.72 & V15 & 0.54 \\
\hline & V1 & 0.40 & V4 & 0.28 & V4 & 0.29 & & & V20 & 0.45 & V14 & 0.47 \\
\hline & & & & & V3 & 0.25 & & & V3 & 0.38 & V1 & 0.41 \\
\hline Negative & V5 & -0.53 & V18 & -0.55 & & & $\begin{array}{l}\text { V1 } \\
\text { V2 }\end{array}$ & $\begin{array}{l}-0.55 \\
-0.54\end{array}$ & & & & \\
\hline
\end{tabular}



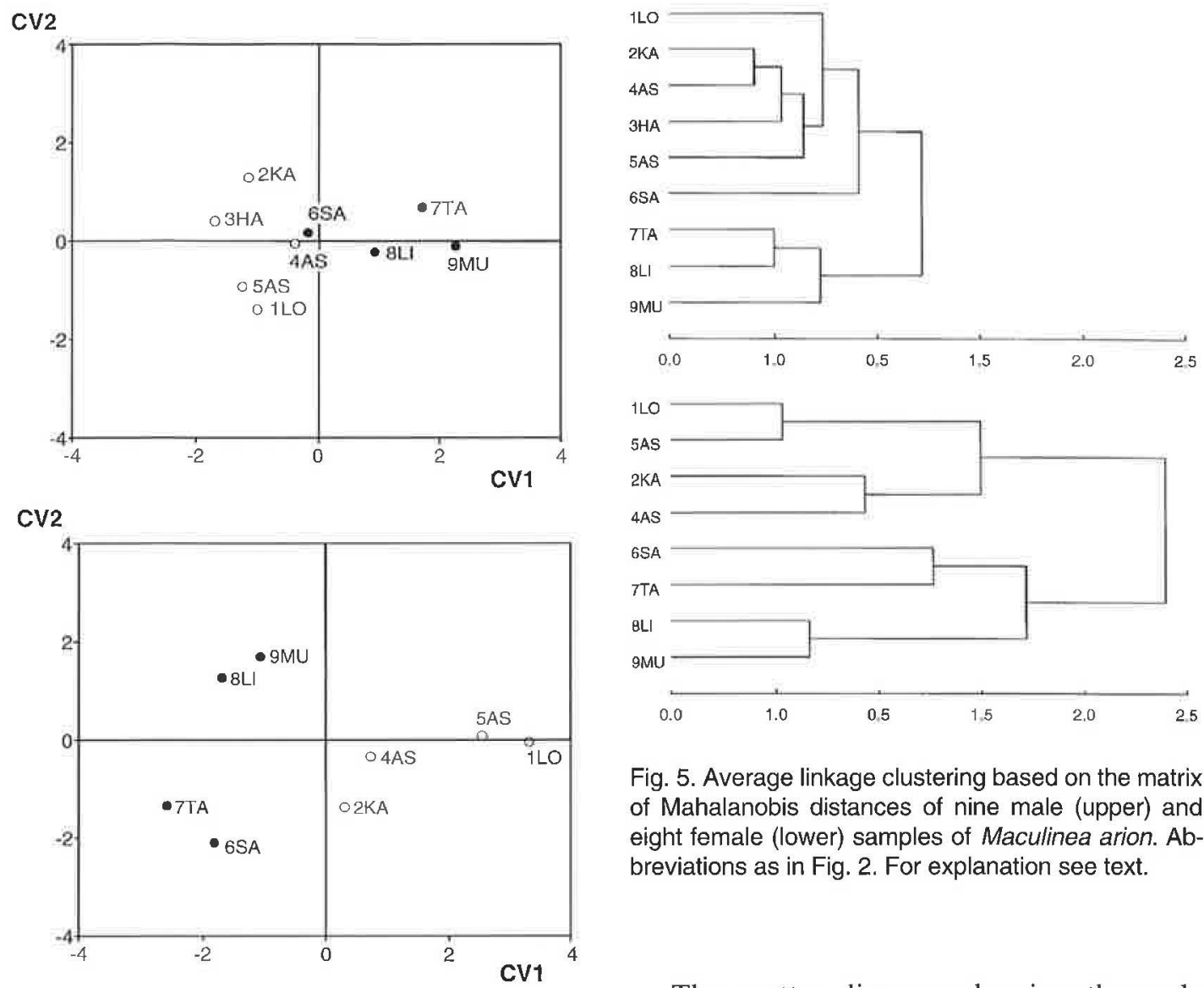

Fig. 4. Sample scores for the first and second canonical variables for Maculinea arion males (upper) and females (lower). For the sample codes, see Fig. 2.

tion and the within-population variation for the corresponding canonical variable. The first three dimensions accounted for $73 \%$ of the variation in the original male data, and $81 \%$ of the variation in the female data.

The first canonical variable correlated best with the measurements related to the size of spots of front wings in both males (V1, V2) and females (V1, V2, V14), and in the case of males also to the width of the marginal stripe (V5). In general, the spots were smaller in the western populations than in the eastern ones, whereas the marginal stripe was wider in the western part of the study area (Table 1). The second canonical variable was associated with V12, V4 and V18 in males, and with V18, V20 and V3 in females.

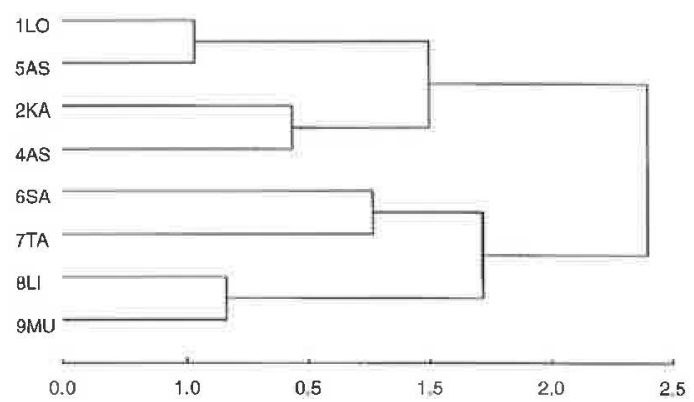

Fig. 5. Average linkage clustering based on the matrix of Mahalanobis distances of nine male (upper) and eight female (lower) samples of Maculinea arion. Abbreviations as in Fig. 2. For explanation see text.

The scatter diagram showing the male populations along the first two canonical axes (Fig. 4) agrees to some degree with the geographical distribution of the population (cf. Fig. 2). The western populations are on the right and the eastern populations on the left, the Saimaa population (6SA) being intermediate. A similar diagram on females (Fig. 4) also kept the eastern and western population separated, though the western populations were on the right and the eastern ones on the left.

Results from the cluster analysis are given in Fig. 5. The analysis revealed that the eastern and western populations formed two strongly differentiated main clusters, their aggregation level being distinctly lower in males than in females. The female population from Saimaa (6SA) was clustered together with the eastern branch, whereas the respective male population was clustered together with the western branch. Temporal within-population variation in Asikkala (4AS) was relatively high compared to the be- 
tween-population variation within both the western and eastern population groups.

\section{Discussion}

The Finnish populations of $M$. arion seem to differ from each other in their wing variation on the basis of several wing variables. The main result was that the western populations are characterized by fewer and smaller spots and wider black fore wing margins than the eastern populations. The border between western and eastern types lies between Asikkala and Saimaa.

The result of the analysis was a feasible simplification of the biogeographical pattern of morphologically differentiated $M$. arion populations in the field. The results from the Asikkala population based on specimens collected during different decades showed that the temporal structure of the material affects the results (see also Väisänen \& Heliövaara 1990, Dempster 1991). The old Asikkala sample resembled morphologically more the eastern populations than the new Asikkala sample, although the difference between those sympatric samples was not very large. The temporal difference provided base-line information for the interpretation of the biogeographical pattern. The results showed that the western populations formed a relatively distinct group, whereas the eastern populations comprised a chain of gradually changing geographically adjacent populations.

The sandy eskers of Finland have been a major dispersal pathway for many animals and plants (e.g. Jalas 1950). The specialized fauna and flora of eskers represent old elements in the Finnish biota, dating at least partly back to the Pre-Boreal Era. Apparently, $M$. arion belongs to this element. It may have arrived in Finland prior to closed pine forests and much before the arrival of spruce (see Alho 1990). The results showed that the Finnish $M$. arion populations are not only marginal extensions of Central European or Russian populations, but represent distinctly differentiated populations, especially in the western part of the country. This increases the conservation value of the Finnish populations beyond the national considerations. It also sets new priorities for conservation: both the eastern and the western populations have to be preserved in order not to lose a substantial part of genetic variation of the species. This does not mean that the long-term survival of $M$. arion would allow the loss of any viable population.

Acknowledgements. We wish to thank Mrs. Hanna Heikkilä, Miss Pirjo Leppänen and Miss Auli Immonen for technical assistance, and Dr. Antti Jansson (Zoological Museum, Helsinki) for the permissions to study the museum materials. Mr. Pekka Koskinen, Gustaf Nordenswan and Henry Holmberg kindly loaned specimens from their private collections. Financial support from the World Wide Fund for Nature (WWF) Finland is gratefully acknowledged. The study belongs to the Finnish Biodiversity Research Programme (LUMO).

\section{References}

Alho, P. 1990: Suomen metsittyminen jääkauden jälkeen. (Summary: The history of forest development in Finland after the last Ice Age.) - Silva Fennica 24: 9-19.

Battin, T. 1992: Geographic variation analysis among populations: the case of Platycnemis pennipes (Pallas, 1771) (Insecta: Odonata: Zygoptera) in the Aegean. — J. Biogeogr. 19: 391-400.

Brakefield, P. M. \& Shreeve, T. G. 1992: Case studies in evolution. - In: Dennis, R. L. H. (ed.), The ecology of butterflies in Britain: 197-216. Oxford Univ. Press, Oxford.

Dempster, J. P. 1991: Fragmentation, isolation and mobility of insect populations. - In: Collins, N. M. \& Thomas, J. A. (eds.), The conservation of insects and their habitats: 143-153. Academic Press, London.

Elmes, G. W. \& Thomas, J. A. 1992: Complexity of species conservation in managed habitats: interaction between Maculinea butterflies and their hosts. - Biodiversity \& Conserv. 1: 155-169.

Heath, J. 1981: Threatened Rhopalocera (butterflies) in Europe. - Council of Europe, Nature \& Environm. Ser. 23: 1-157.

Henriksen, H. J. \& Kreutzer, I. 1982: The butterflies of Scandinavia in nature. - Skandinavisk Bogforlag, Odense. 215 pp.

Higgins, L. G. 1975: The classification of European butterflies. - Collins, London. 320 pp.

Higgins, L. G. \& Riley, N. D. 1970: A field guide to the butterflies of Britain and Europe. - Collins, London. 380 pp.

Jalas, J. 1950: Zur Kausalanalyse der Verbreitung einiger nordischen Os- und Sandpflanzen. -... Ann. Bot. Soc. Vanamo 24(1): 1-362.

Järventausta, K., Avanto, A., Finneman, J. \& Haarto, A. 1988: Varsinais-Suomen suurperhosfauna 1870-1987. - Turku. 151 pp. 
Kesküla, T. 1992: Distribution maps of Estonian butterflies (Lepidoptera: Hesperioidea, Papilionoidea). Acta Mus. Zool. Univ. Tartuensis 6: 1-60.

Muggleton, J. \& Benham, B. R. 1975: Isolation and the decline of the large blue (Maculinea arion) in Great Britain. - Biol. Conserv. 7: 119-128.

Nordström, F., Opheim, M. \& Valle, K. J. 1955: De fennoskandiska dagfjärilarnas utbredning. Lepidoptera Diurna (Rhopalocera \& Hesperioidea). - Kungl. Fysiogr. Sällsk. Handl., N. F., 66 (1): 1-176.

Podani, J. 1990: SYN-TAX IV. Computer programs for data analysis in ecology and systematics on IBM-PC and Macintosh computers. User's manual, - UNIDO, International Centre for Science and High Technology, International Centre for Earth, Environmental and Marine Sciences and Technologies, Trieste, Italy. 145 pp.

Rassi, P., Alanen, A., Kemppainen, E., Vickholm, M. \& Väisänen, R. (eds.) 1986: Uhanalaisten eläinten ja kasvien suojelutoimikunnan mietintö. II. Suomen uhanalaiset eläimet. - Ministry of the Environment, Komiteanmietintö 1985: 43(2): 1-466.
Rassi, P., Kaipiainen, H. Mannerkoski, I. \& Ståhls, G. (eds.) 1992: Uhanalaisten eläinten ja kasvien seurantatoimikunnan mietintö. - Ministry of the Environment, Komiteanmietintö 1990: 30: 1-328.

Thomas, J. A. 1983: Large blue butterflies. - In: Wells, S. M., Pyle, R. M. \& Collins, N. M. (eds.), The IUCN red data book: 451-457. IUCN, Gland.

- 1984: The conservation of butterflies in temperate climates: past efforts and lessons for the future. Symp. R. Entomol. Soc. London 11: 333-353.

Thomas, J. A. \& Wardlaw, J. C. 1992: The capacity of a Myrmica ant nest to support a predacious species of Maculinea butterfly. - Oecologia (Berlin) 91: 101109.

Thomson, E. 1967: Die Grosschmetterlinge Estlands. Helmut Rauschenbusch Verlag, Stollhamm. 203 pp

Väisänen, R. \& Heliövaara, K. 1990: Morphological variation in Aradus cinnamomeus (Heteroptera, Aradidae): discrimination between parapatric alternate-year populations. - Ann. Zool. Fennici 27: 2947. 